University of Colombo Review (Series III),

Vol. 1, No. 1, 2020

\title{
Sri Lankan Out-Migration: Five Key Waves Since Independence
}

\author{
Pavithra Jayawardena \\ Senior Lecturer, Department of International Relations, University of Colombo
}

ABSTRACT
Sri Lankan migration provides a mini-laboratory for migration
scholars because of its rich diversity. The "Sri Lankan Tamil diaspora,"
the "Sri Lankan maid," the "Sri Lankan refugee," and the "Sri Lankan
boat migration to Australia" are some examples of the diversity and
complexity of the phenomenon. At present, Sri Lanka has a total of
three million emigrants of which one million have permanently settled
outside Sri Lanka. This permanently settled community constitutes
a one to twenty diaspora to population ratio, a significantly unique
ratio for any sending country. Nonetheless, a holistic understanding
of Sri Lankan migration is lacking, even though selective aspects of
the phenomenon have received some academic attention. This article
intends to fill this gap by providing a broader overview of Sri Lankan
migration since its Independence. Through a thorough review of
related academic articles and fifty-one semi-structured interviews with
Sri Lankan emigrants, this article summarizes the key elements of Sri
Lankan migration in five main waves from Independence until today.
By revealing the diversity of the Sri Lankan immigrant community and
its complexity, the article suggests the importance of understanding
any immigrant community holistically not only for a better scholarly
understanding but also effective policy making.

\section{KEY WORDS:}

Sri Lankan migration, sending countries, receiving countries, Tamil diaspora, Sinhalese migrants.

Suggested Citation: Jayawardena P. (2020). Sri Lankan Out-Migration: Five Key Waves Since Independence. University of Colombo Review (Series III). 1 (1). 101 - 118

(c) 2020 The Authors. This work is licenced under a Creative Commons Attribution 4.0 International Licence which permits unrestricted use, distribution, and reproduction in any medium, provided the original work is properly cited. 


\section{Introduction}

At a diplomatic event in Colombo to celebrate bilateral relations between Sri Lanka and a European country in 2019, a Sri Lankan high-level foreign service official was asked to share some basic information about the Sri Lankan immigrant community living in that European country. Unfortunately, the Sri Lankan foreign service official failed to disclose any related information. Instead, a diplomat from that European country revealed some of their statistics about the Sri Lankan immigrant community in that country. An example of Sri Lanka's institutional failure of many years on maintaining records on its emigrants (Dias \& Jayasundere, 2004; Sriskandarajah, 2002; Ukwatta, 2013), it is nevertheless a common fact that receiving countries maintain information about immigrants more extensively and reliably than many sending countries.

A variety of reasons contribute to this fact. Sending countries' interest in building up relations with their emigrants and introducing emigrant out-reach policies are relatively new. Until recently, many sending countries ignored investing time and energy to search or keep track of their emigrants. The sending countries' traditional thinking was that if a person leaves a country, it is because that person is not loyal to the State (Kivisto \& Faist, 2010). Therefore, sending countries saw no reason to record information about its emigrants for years. However, during the last few decades, there has been a shift towards connecting with emigrants due to many reasons. Some of those reasons, according to Kivisto and Faist (2010) are, the understanding by sending countries of the identity-issues of their emigrants, the realization of economic benefits that emigrants can bring to the country, and the rise of the human rights movement.

Due to the lack of data that captures the dimensions of migration from sending countries, researchers on migration largely depend on sources provided by international organizations and receiving countries. While some of these sources offer rich data, for example institutions such as the International Organization for Migration (IOM), others do not. Specifically, most sources within receiving countries such as their census reports or other surveys largely report information about individual immigrants and details about their lives in the receiving country only. Most of this data does not include contextual or group/community realities faced while in the sending country which have an enormous effect on immigrants' lives. As Yang (1994) argues, it is imperative to study both receiving and sending country dimensions in exploring migrants; to get a deeper knowledge of the phenomenon. If a researcher depends solely on sources that do not represent the sending country's impact on migrants' lives, I argue, such researchers are likely to fail in adopting a holistic approach to understand the category of the migrant.

This article argues, therefore, for migration research data that captures home country elements for two key reasons. Firstly, from a policy point of view, having records that assist policy makers understand migrants contextually is essential in order to make more effective policies for migrants, i.e., for home country policy makers to design more effective emigrant out-reach policies and for adoptive country policy makers to design more effective policies on immigrants' naturalization and integration. Secondly, from an academic point of view, it allows migration researchers to produce more reliable new knowledge about migrants with adequate representation of the complexities of migrants' lives. 
It should be noted that I use the term Sri Lankan migrant community as a broad term that includes a range of different types of Sri Lankan migrants; i.e., ethnically, demographically or class-wise. I acknowledge that the Sri Lankan migrant community is diverse in many respects, and has intense internal rivalry (ethnic tensions between Tamils vs. Sinhalese), different economic abilities (skilled migrants vs. unskilled labour migrants), and incompatible levels of social capital (first generation migrants vs. second generation migrants and their integration into the host society). Taking into consideration these differences, mainly the ethnic tension between Sinhalese and Tamils, Reeves (2013) noted that we cannot consider the "Sri Lankan diaspora" as a single entity. This is because it functions as two separate groups: "Sri Lankan diaspora" and "Sri Lankan Tamil diaspora" (Perera, 2020; Wayland, 2004).

I highlight the heterogeneity of the Sri Lankan migrant community by first providing a comprehensive overview of Sri Lankan migration, specifically since Independence. I then divide Sri Lankan migration into five key waves and present the specificities of each wave separately, emphasizing the complexities of the phenomenon. I conclude the article with a summary of existing knowledge on Sri Lankan migration and potential areas for future research. The data is drawn from two key sources: a) relevant scholarship on several specific aspects of Sri Lankan migration and b) fifty-one interviews with Sri Lankan migrants who left Sri Lanka in the 1960s until 2019. In brief, the article attempts to assist readers to obtain a broader overview of the diversity and complexities of Sri Lankan migrant communities since Independence.

\section{An Overview of Sri Lankan Migration}

Migration has played an essential role in shaping Sri Lanka's history. It is believed that the Sinhalese people (presently the majority ethnic group) evolved from the Aryan people who came to Sri Lanka in the 5th century BC from Northern India (Cassim, 2017). Meanwhile the Tamil people (presently the second largest ethnic group) evolved from Dravidian people who arrived in Sri Lanka from the Southern part of India (Reeves, 2013). Before that, the indigenous people, called Veddas, lived in the country (Reeves, 2013). Sri Lanka was colonised by the Portuguese in 1505 until the Dutch colonised the land in 1658 (Bandarage, 2008; Cassim, 2017). Since 1796 the British colonised the country until Sri Lankan Independence in 1948 (Bandarage, 2008; Cassim, 2017). There are some records of Sri Lankan emigrations that took place during the British colonial period. Some Sri Lankans who were from elite families migrated for their higher studies, primarily to Great Britain (Sriskandarajah, 2002). According to Eelens (1995) and Ratnayake (1999), British colonial rulers also sent a group of Sri Lankan Tamils to Malaysia for labour. Gamage (1998), Pinnawala (1984) and Weerasooria (1988) found that 500-1000 Sri Lankan labour migrants were also brought to Australia to work in sugar plantations in Queensland and the pearl fisheries in the Torres Strait.

Since Independence in 1948 until today, Sri Lankan migration has become a minilaboratory for migration research due to its unique features. During this period, Sri Lanka has produced different types of migrants, from highly skilled to non-skilled migrants, 
from students to refugees, from economic to political migrants and from legal to irregular migrants. The "Sri Lankan maid" and the "Sri Lankan refugee" are now renowned throughout the world and have affected Sri Lanka's image as a migrant-sending country in many ways (Sriskandarajah, 2002). "Sri Lankan Tamils" has become a model in the concept of transnational identity (Burgio, 2016) and theory on diaspora (Cheran, 2003). "Sri Lankan boat migration to Australia" has also gained a lot of attention in both academia as well as at policy levels (Howie, 2013; Hugo \& Dissanayake, 2017).

According to Reeves (2013) and Sriskandarajah (2002), the Sri Lankan migrant community produces a remarkable diaspora to population ratio, i.e., approximately one in every twenty Sri Lankans is permanently settled outside Sri Lanka. The total population of Sri Lanka is recorded as 21.8 million (Central Bank of Sri Lanka, 2019). Sri Lanka is a multicultural, multi-ethnic and a multi-religious country with $74.9 \%$ Sinhalese (majority ethnic group), $11.2 \%$ Tamils, 4.1\% Indian Tamils, 9.3\% Moor and 0.5\% others (Department of Census and Statistics, 2012). According to Reeves (2013), the total number of Sri Lankan emigrants is calculated at three million. This includes the two million temporary labour migrants who live in the Gulf area, on short term job contracts with the explicit intention of returning to Sri Lanka. Of the one million permanently settled Sri Lankan emigrants, nearly 500,000 live in the Americas, 400,000 in Europe, and around 70,000 in Australasia. Other sources, such as the International Crisis Group (2010) claim that the permanently settled Sri Lankan diaspora amounts to two million. The United Nations (as cited in Hugo \& Dissanayake, 2017) has shown that there were 1.25 million Sri Lankan-born persons living outside of their country of birth, equivalent to 5.9 per cent of the current Sri Lankan resident population. Due to these high numbers and the intensified impact of Sri Lankan emigrants in several receiving countries, Sri Lanka is known as one of the significant emigration nations in the contemporary world (Hugo \& Dissanayake, 2017).

Enormous economic, social and cultural changes that took place in Sri Lankan society, shifts in the global labour and financial markets, as well as receiving countries' migration and citizenship policies and modes of migration are key reasons that made Sri Lankan migration more complex (Cheran, 2003; Gamage, 2002; Hugo \& Dissanayake, 2017; Hugo \& Ukwatta, 2010; Ukwatta, 2013). Jayasuriya and McAuliffe (2017) categorized Sri Lankan emigrants into five groups as temporary workers (skilled, semi-skilled and unskilled), skilled settlers, students, asylum seekers and tourists (including pilgrims to Nepal and India). Meanwhile, Wanasinghe-Pasqual and Jayawardena (2017) identified five key waves of Sri Lankan emigration since Independence. In the next sections of this article I expand on this scholarship.

\section{The First Wave}

The first wave of migration from Sri Lanka occurred immediately after the country gained Independence from Britain in 1948. Shortly after, it is reported that a few Sri Lankans migrated to Singapore and Hong Kong (Eelens, 1995; Ratnayake, 1999). However, records on this are sparse. The most notable wave of emigration at this time was of Ceylonese Burghers of European descent (Gamage, 1998, 2002; Pinnawala, 1984). The main push 
factor for their emigration was the power shift with Independence from colonial masters to local authorities. Even though the Burgher community was numerically small, during the colonial period, they were powerful and played a critical role in government institutions (Horowitz, 1980). The departure of the European colonial masters generated fear in the Burgher community about their lives in Sri Lanka under a different local government. According to Pinnawala (1984), it was mostly the Dutch Burghers who emigrated from Sri Lanka during this period, while some Portuguese-Burghers also managed to leave the country.

While Independence was a key push factor that affected the migration of the Burghers, certain pull factors from within host countries also influenced their move. For example, Burghers received assistance to migrate to Western countries such as Britain and Australia because of their European descent (Gamage, 1998, 2002; Pinnawala, 1984): the White Australia policy (Australian Government, 2018) being one such example. Pinnawala (1984), in his investigations, found that Burghers could provide their Baptism or birth certificates to easily prove their eligibility to arrive in Australia as a "full blooded Burgher" under the White Australia policy. In certain exceptional circumstances, some Burghers arrived in Australia through falsification of evidence and favours from high-level authorities (Pinnawala, 1984). However, it is not clear how many Burgher people emigrated at this time, although it is presumed that a considerable number of them did.

\section{The Second Wave}

The second wave of migration occurred after 1956 when the Sri Lankan government introduced controversial national language reforms (the Sinhala Only Act). The new Act made the majority ethnic language, Sinhala, the national language of the country (Gamage, 1998; Wayland, 2004). The departure of the Burgher community was intensified by this introduction of the Sinhala only language policy as many of them were not fluent in the language (Gamage, 1998).

In an interview, Anthony, a 77-year-old Sri Lankan Burgher, Catholic male who is currently living in Sydney, mentioned that he arrived in Australia by ship in 1963 when he was twenty-one years old. His decision to leave Sri Lanka was highly influenced by the introduction of the Sinhala Only language policy (the push factor) and supported by the White Australia policy of the time (the pull factor). He said:

Well, we started getting difficulties for Burghers in Sri Lanka. With the change of language policies, we found it difficult to enter a university. I actually was selected for the University of Peradeniya. I actually went one year there. But then, we understood that there is no future for Burghers in Sri Lanka. So, we came to Sydney. We had an aunt and uncle living here already. Uncle was a doctor here in Sydney. Then we stayed with them.

Anthony also stated that many other Sri Lankan Burghers migrated to countries like the United Kingdom, Canada, New Zealand and Australia at the time. He said "the majority of them came to Australia. Most of them stayed in Melbourne." As he recalled, getting 
permission to enter Australia as a Dutch-Burgher was not difficult for Anthony. He noted that the Sri Lankan Dutch-Burghers had a good reputation in Australia at the time. Some native Sri Lankans who were partners or family members of Burghers also migrated from Sri Lanka to Western countries during this wave (Pinnawala, 1984).

Apart from the Burghers, Sinhalese and Tamils from English educational backgrounds who could not work in Sinhala and were from a westernized upper class also decided to leave Sri Lanka. They feared that they would not be able to continue their professional work in the Sinhala language (Gamage, 1998). According to de Silva (1967), the language policy change in 1956 was a lower middle-class assault on the privileged upper class that ultimately led to the latter's migration overseas.

Another factor that contributed to the promotion of migration among Burgher elites during this time was the coup attempt of 1962. The coup was planned by some high-ranking military officers among whom were a considerable number of Burghers (Horowitz, 1980). When it failed, some officers were immediately arrested, leading other elite Burghers (and also Tamils) to migrate from Sri Lanka (Roberts, 1983).

\section{The Third Wave}

The third wave occurred in the early 1970s. The socialist-oriented government of Sri Lanka at the time intervened in all the industries, imposing restrictions on imports and foreign travel (Gamage, 1998). The government also introduced drastic nationalization reforms (Athukorala \& Jayasuriya, 2000). This resulted in numerous economic hardships for every type of family, including the unavailability of food, medicine and other essential services, and led some professionals to emigrate in the hope of earning better salaries and obtaining a good education for their children in a developed country (Dias \& Jayasundere, 2004; Gamage, 1998; Ratnayake, 1999; Ukwatta, 2013). According to Gamage (1998), various fee restrictions put in place by the government against some professional groups also contributed to their decision to migrate.

The group of professionals that left Sri Lanka in this period includes doctors, engineers, accountants, managers, scientists, technologists and navigators (Dias \& Jayasundere, 2002). According to Sriskandarajah (2002), this group provides a clear example of brain drain from Sri Lanka. These Sri Lankan professionals largely migrated to countries such as Australia and Canada, and to some European countries such as Great Britain, Switzerland and Germany (Henayaka-Lochbihler \& Lambusta, 2004). They also migrated to countries such as Nigeria and Papua New Guinea (Sriskandarajah, 2002). There were both Sinhalese and Tamil professionals. While the concern of Sinhalese professionals was mainly economic hardships, the decision of Tamil professionals was influenced by both economic hardship and ethnic discrimination caused by the Sri Lankan government's employment and language policies (Sriskandarajah, 2002).

In addition to these internal push factors, relaxation of immigration regulations in countries such as Australia, Canada, New Zealand and the USA from the 1970s onwards became pull factors (Galligan \& Roberts, 2003; Koleth, 2010; Kymlicka, 2003; Office of Multicultural Affairs, 1989; Singham, 2006; Zubrzycki, 1995). Countries such as Canada 
pioneered in promoting "multiculturalism" as a core principle of their immigration policies. Following Canada, countries like Australia and New Zealand also relaxed their immigration policies and promoted diversity. For example, Australia replaced its White Australia policy in 1973 with multiculturalism, encouraging Asian arrivals to the country for the first time (Koleth, 2010).

During the 1970s, another set of Sri Lankan migrants left Sri Lanka on several scholarships. As noted above, temporary migration for education was not a new phenomenon. Nonetheless, during earlier periods, these temporary student migrants were mainly from elite Sinhalese and Tamil families. However, by the late 1970s, thousands of students migrated for study through a number of scholarship schemes. A considerable number of Tamil students emigrated through these scholarships as they found it difficult to obtain admissions to Sri Lankan universities in the early 1970s as a result of quota limitations on Tamil students (Sriskandarajah, 2002).

In 1977, Sri Lanka's closed economic approach changed significantly with the new right-wing government of the United National Party which introduced an open economy and aimed at increasing the role of the private sector in the national economy (Dias \& Jayasundere, 2004). During this period, there was an emerging economic boom in the Middle East which opened the doors for a range of employment opportunities. Seeing the potential of this new development, the government relaxed some regulations on travel and foreign exchange convertibility to facilitate overseas work and remittances (Sriskandarajah, 2002).

According to Dias and Jayasundere (2004), by the mid-1970s, a group of skilled labour in the construction field migrated to the Middle East. By 1979, this skilled migrant group had diversified to include drivers, carpenters and mechanics. Records show that 1,913 skilled migrants had departed from Sri Lanka by 1985, starting from zero in 1975 (Dias \& Jayasundere, 2002). Unskilled workers who migrated to the Middle East mostly included housemaids and other workers, and these numbers rose quickly from zero in the early $1970 \mathrm{~s}$ to 9,024 by the mid-1980s (Dias \& Jayasundere, 2002). Nonetheless, it is important to note that there are questions about these numbers. Due to the closed economic policies in place before 1977 and poor data collection on migration, only a few records remain on migration at this time (Dias \& Jayasundere, 2002).

\section{The Fourth Wave}

I suggest that the fourth wave of Sri Lankan migration occurred in the 1980s, marking a watershed in migratory patterns. While the migrants discussed in earlier waves continued to migrate, a new group of "forced migrants" became a critical component of the Sri Lankan migrant community during this period. These migrants were forced to leave the country due to the two armed conflicts that erupted simultaneously in Sri Lanka: the separatist war in the north and east, and the JVP insurrection in the south of the country (Siriwardhana \& Wickramage, 2014; Sriskandarajah, 2002).

The conflict in the north and the east was the result of years of discrimination by the Sri Lankan State of Tamil citizens, an ethnic minority. The demand by Tamil leaders for 
a federal system with autonomy for the northern and eastern regions of the country was repeatedly refused by Sinhalese-Buddhist dominated governments (Samaranayake, 1990; Wayland, 2004). Consequently, there was a rise of ethno-nationalist Tamil identity and a claim for a separate Tamil state of "Eelam" (Sankaran, 2019; Wayland, 2004). A separatist group called the Liberation Tigers of Tamil Eelam (later identified by the United Nations as a terrorist group - internationally known as LTTE or Tamil Tigers) took arms against the government of Sri Lanka due to the systematic discrimination of Tamils in favour of the majority ethnic group, the Sinhalese (Arunatilake et al., 2001).

This ethnic division intensified with the 1983 ethnic riots across the country by Sinhalese against Tamils with the intention of teaching Tamils a lesson (Roberts, 2005). According to some records, the 1983 race riot resulted in 3,000 Tamil deaths (Sriskandarajah, 2002) and hundreds of Tamils leaving Sri Lanka as refugees or on other humanitarian grounds. The records show that from 1983 to 2010, there was a total of 73,000 Sri Lankan refugees who lived in 112 camps in Tamil Nadu, followed by another 34,000 outside the camps (Pagonis, 2010). The violence of 1983 also influenced Tamil migrants who were already living in Europe and North America as students or guest workers to stay on permanently (Sriskandarajah, 2002). Thus, the 1983 race riots marked the turning point of Tamils' migration from Sri Lanka. Since then until 2000, the United Nations High Commission for Refugees (UNHCR) ranked Sri Lanka as one of the top ten asylum seeker sending countries (as cited in Sriskandarajah, 2002). By 2001, the total number of internationally displaced Sri Lankan Tamil was estimated at 817,000 (United Nations High Commission for Refugees, 2006).

In fact, the 1983 riot drew international attention to the situation of Sri Lankan Tamils and as a result, Sri Lankan Tamil migration is largely understood as a post-1983 phenomenon. However, Ratnapalan (2014) opposes taking 1983 as the pivotal moment of Sri Lankan Tamil migration, suggesting, rather, that it is imperative to explore Sri Lankan Tamil migration through a historical perspective which would include, for example, Tamils who left Sri Lanka in the 1950s and 1960s.

The conflict in southern Sri Lanka also produced several forced migrants who were mostly Sinhalese. This conflict was led by the Janatha Vimukthi Peramuna (known as JVP or the People's Liberation Front), a radical Marxist youth group (Arunatilake et al., 2001; DeVotta, 2007; Samaranayake, 1990). When the JVP sought to topple the Sri Lankan government in 1971, it was crushed, resulting in over ten thousand deaths (DeVotta, 2007). The JVP's second uprising in 1988/89 was based on opposition to the 1987 Indo-Lanka Accord under which the Sri Lanka government permitted the intervention of Indian Peace Keeping Force in managing the conflict in the north (Samaranayake, 1990). The JVP had, by this time, changed its original sympathetic position regarding the plight of the Tamils and shifted towards a more Sinhala-Buddhist nationalistic rhetoric (Arunatilake et al., 2001; Pinnawala, 1984). This second insurrection was crushed again by the government with over 20,000 youth deaths (DeVotta, 2007). While the conflict in the north and east forced Tamils to migrate as refugees or asylum seekers, the southern conflict led to Sinhalese migrating on similar humanitarian grounds (Gamage, 1998; Sriskandarajah, 2002). 
Meanwhile, the previous professional emigrant category continued (Gamage, 1998). However, unlike in the earlier waves, Tamil migration surpassed the Sinhalese significantly in the 1980s. Sriskandarajah (2002) noted that Tamil migration from Sri Lanka after 1983 does not only contain those who sought asylum on arrival in the West through informal routes but also skilled migrants, as well as those who arrived on family reunion programs and as political refugees. Another main difference was that the emigrants in this fourth wave had a united ethnic identity either as a "Sinhalese" or a "Tamil," shaped by their intense domestic experiences (Perera, 2020; Wayland, 2004).

In the early 1980s, labour migration also extended from the Middle East to East Asia due to the increased demand for labour as a result of East Asian economic growth (Dias \& Jayasundere, 2002). During this time, a visible feminization of labour migration also took place with sixty five per cent of the recorded number of Sri Lanka's labour migrant population reported to be women (Collyer et al., 2009; Dias \& Jayasundere, 2004). These women left Sri Lanka as unskilled housemaids. The key factor that led to these women seeking employment in the Middle East was the higher rate of female unemployment in Sri Lanka (Dias \& Jayasundere, 2004) and the devaluation of the rupee (Sriskandarajah, 2002). Being able to earn nearly eight times more than they would in Sri Lanka was a key determinant that encouraged these women to migrate (Farrag, 1997).

Another push factor that affected women's labour migration was governmental policies that facilitated foreign employment during the 1980s (Ukwatta, 2013). The Sri Lanka Bureau of Foreign Employment (SLBFE) was established in 1985, repealing the Foreign Employment Agency. Since then, there has been a drastic increase in labour migration. According to Sriskandarajah (2002), the government supported the outflow of labour for two key reasons. On the one hand, it eased the problem of local unemployment. On the other hand, the remittances from these migrants contributed significantly to national income. The SLBFE Act No. 21 of 1985 sets out the functions and general powers of the SLBFE. It also sets out strict rules relating to foreign employment agencies and regulations on collecting data on migrant workers (Dias \& Jayasundere, 2004). Even though there were certain loopholes in the Act, overall, it helped to safeguard migrant workers (Dias \& Jayasundere, 2004). By the mid-1980s, the number of migrant workers in the Middle East was reported as 16,656 and by 2009 , the total number of foreign contract workers was estimated at 1.67 million (Ukwatta, 2013).

Migration to Italy began through formal channels. The first recorded entrance to Italy by Sri Lankans was reported during the 1970s when Sri Lankan Catholic women were recruited for working in old people's homes in Italy. During the 1980s, Italy became a popular destination because of employment opportunities there and better admission possibilities than in any other European country. In particular, between 1986 and 1990 a series of Immigration Admission Acts in Italy attracted many Sri Lankans (HenayakaLochbihler \& Lambusta, 2004). By 1995, the Dini Decree (Government of Italy) further simplified administrative procedures for family reunions. This enabled a larger number of Sri Lankans to join their family members in Italy. 
However, during this period, some Sri Lankan migrants also entered Italy illegally, mostly using irregular maritime channels through the Balkans or Austria. These irregular journeys were assisted by some travel agencies and import-export enterprises (Morlicchio as cited in Henayaka-Lochbihler \& Lambusta, 2004). Pathirage and Collyer (2011) identified that illegal migrants to Italy, specifically from the Catholic fishing village of Wennappuwa, had a strong social network to carry out their undocumented migration strategies. The irregular maritime arrivals dropped significantly, however, after 2002 when the Italian parliament introduced a new immigration law called the Bossi-Fini law (Government of Italy) that placed strict border controls and regulation of immigrants.

For Sri Lankan migrants, Italy was perceived as a temporary destination at the beginning but became the next available option when attempts to migrate to Great Britain, Germany, Switzerland or France failed (Henayaka-Lochbihler \& Lambusta, 2004). Nonetheless, most of the Sri Lankan immigrants to Italy have chosen to settle there permanently. This decision was influenced by two factors. The first was the higher economic prosperity Italy could offer Sri Lankan immigrants in comparison to income from within Sri Lanka. The second was the creation of the Schengen area in 1995. When Italy became a Schengen country, the value of receiving an Italian passport increased significantly. Through an Italian passport, immigrants could then enter twenty-five other European States. A considerable number of Sri Lankan immigrants who first arrived in Italy have, thereby, now migrated to other European countries. UK is also a popular destination among Sri Lankans because even though UK is not a Schengen country, Sri Lankans who are European citizens enjoy special rights to enter, live and work there.

Several aspects of Sri Lankan immigration to Italy have been studied. For example, Brown (2014) explored the perceptions of young Sri Lankans on migrating to Italy. He found that they are inspired by the high-income opportunities in Italy as well as the social status of Sri Lankan immigrants in Italy. Studying the cosmopolitanism amongst Sri Lankan Catholic migrant workers, Brown identified, however, that they feel lonely because they find integrating with the host society challenging. Näre (2010) investigated how the masculinist ideology of Sri Lankan immigrants complements or contradicts the types of jobs they perform in Italy which are stereotypically known in Sri Lanka as women's jobs.

\section{The Fifth Wave}

From 2000, a new wave of migration intensified with students migrating for educational purposes. As discussed above, leaving Sri Lanka for study purposes is an old phenomenon that goes back to pre-Independence times. These migrants were mainly from elite or upper-middle-class families or those who migrated on scholarships. Nonetheless, the fifth migration wave that began in the early 2000s and continues today includes a considerable proportion of Sri Lankan students from urban and rural middle-class families.

This new increase of migrants for study purposes is the result of the popularity of "studying abroad" which not only means migrating for study and returning, but also settling in a Western developed country. Since 2000, there has been a sharp increase in the number of foreign education agencies. These agencies promote "studying abroad" 
through newspapers, radio, TV and social media advertisements with messages on potential places for overseas study (Jayasuriya \& McAuliffe, 2017). Australia, New Zealand, United Kingdom, USA and Canada have become popular study destinations. Since studying in a foreign university has become popular and is perceived as a worthy investment that lays the foundation for settling in a developed country, even families without adequate finances take loans to send their children abroad. They consider this as a lifetime investment. A majority of them use education as a means to enter a country like Australia or New Zealand and then take measures to settle down in those countries. This form of emigration is also the result of middle and lower-middle-class dissatisfaction with domestic conditions (Pingama, 2016).

Samitha is a 40-year-old Sinhalese Buddhist male who lives in Auckland, New Zealand. He arrived in New Zealand in 2005 as a student. His migratory intention was to settle down in New Zealand after his studentship. He noted that it was the Sri Lankan economy that mainly influenced him to migrate.

Well, in Sri Lanka, it is very difficult to find a job that will give us a life we want. [Even if you find a job,] no matter how big the salary is, it is always difficult to have a good life. When we watch movies, we think a good life should be like that, but in Sri Lanka, we cannot have a life like that. [I decided to migrate from Sri Lanka] mainly because of the economic reasons.

Records of the numbers of migrants who left Sri Lanka as students are unreliable at the Sri Lankan end. This is because, there is no Sri Lankan authority with whom those who migrate overseas for study have to register. However, Jayasuriya and McAuliffe (2017) developed the following table with information from the Organization for Economic Cooperation and Development. The table shows a slow but steady rise in Sri Lankan student migrants.

Table 1: International students from Sri Lanka in OECD countries

\begin{tabular}{|l|r|r|r|r|r|r|}
\hline Destination & $\mathbf{2 0 0 4}$ & $\mathbf{2 0 0 5}$ & $\mathbf{2 0 0 6}$ & $\mathbf{2 0 0 7}$ & $\mathbf{2 0 0 8}$ & $\mathbf{2 0 0 9}$ \\
\hline Australia & 2,117 & 2,082 & 2,499 & 3,550 & 4,073 & 4,296 \\
\hline United Kingdom & 2,267 & 2,419 & 2,765 & 3,005 & 3,141 & 3,553 \\
\hline United States & 1,964 & 2,081 & 2,234 & 2,425 & 2,594 & 2,927 \\
\hline Japan & 615 & 765 & 867 & 1,155 & 1,197 & 1,098 \\
\hline Canada & 161 & $\begin{array}{r}\text { Not } \\
\text { available }\end{array}$ & 252 & 186 & 271 & 309 \\
\hline Total & 7,603 & 7,855 & 9,125 & 10,915 & 12,049 & 13,065 \\
\hline
\end{tabular}

Source: Organization for Economic Co-operation and Development as cited in (Jayasuriya \& McAuliffe, 2017).

While middle-class families invested in sending their children to Western countries for education, lower-class families also took risks to enter Australia through irregular maritime channels. Migration through irregular maritime channels is not new in Sri Lankan migration. As discussed above, a considerable number of Sri Lankan migrants had entered Italy through irregular means. However, irregular migration from Sri Lanka to Australia by boat grew into a new wave after the 2000s (Brown, as cited in Hugo \& Dissanayake, 
2017). This occurred not only from Sri Lanka but also from refugee camps in India when Tamil refugees attempted to sail to Australia illegally (Doherty, 2011). The period between 2012-2013 records the peak of such activity with a sudden influx of over 6,000 Sri Lankans arriving on Australian shores seeking asylum during this period (Howie, 2013; Hugo \& Dissanayake, 2017). This is a drastic rise in Sri Lankan boat migration to Australia, in comparison to the number in 2008 which was only two hundred. On detection, these migrants were sent to Christmas Island. Some of them refused and decided to return to Sri Lanka instead (Hodge, 2012).

The migrants who, seeking asylum, used irregular maritime means to enter Australia were not only Tamil. It is reported that in 2012, 13 per cent of the irregular migrants were Sinhalese (Jayasuriya \& McAuliffe, 2017). Thus, Hugo and Dissanayake (2017) argue that "protection" was not the sole reason for Sri Lankan irregular maritime arrivals in Australia. There were other socio-economic push factors within Sri Lanka that gave rise to such boat migrations. In their research, Hugo and Dissanayake (2017) found that many of these irregular maritime migrants were unemployed or in low paid work as fishermen, drivers, farmers or labourers.

For example, Selvan, a twenty seven year old Tamil man from Trincomalee who tried to enter Australia as an irregular migrant revealed to Hugo and Dissanayake (2017) that it was not "protection" he expected through his boat journey to Australia but some economic and social stability. He said:

I am still unemployed because I have studied up to GCE (O. L.) but was not successful. My family still supports me because my brother is in England, and the sister lives in Canada. I can communicate in English to some extent. I also have some relatives living in Australia. I am very much frustrated because only I have this low standard of living in Sri Lanka. For these reasons I decided to migrate to Australia by boat because one of my friends who went to Australia by boat suggested to me that it saves time and money. Although the bad memories of the war are over, there are many jobless youth, so I was expecting better opportunities in Australia.

Apart from these new types of student and irregular maritime migrants, all other groups of migrants such as professionals, highly skilled, semi-skilled and unskilled continue the outflow of migrants from Sri Lanka today. Meanwhile, a trend of leaving for Korea to work has become significantly visible with twenty eight thousand Sri Lankan migrants journeying to Korea under its Employment Permit System to work in both semi-skilled and unskilled jobs between 2014 to 2019 (Wijayasiri, 2019). Factors such as higher incomes, no requirement of educational or professional qualifications and low pre-departure costs have contributed to the growing interest amongst Sri Lankan labour of leaving for Korea (Wijayasiri, 2019).

In this fifth wave, there is also an increase of Sri Lankan outbound tourists. As the Sri Lanka Tourism Development Authority (2018) reports, 1,475,929 Sri Lankans travelled overseas in 2018. The number of Sri Lankan tourists who went on pilgrimages to countries such as India, Nepal and Thailand also increased. However, statistics and information about specific migrant tourist groups per destination is sparse. Meanwhile, India, which is Sri 
Lanka's geographically closest neighbour reported that Sri Lankan tourists are among the top ten sources for the Indian tourism market (High Commission of India in Sri Lanka, 2020).

As discussed above, Sri Lankan migration is a complex phenomenon of which a number of selective aspects have attracted relatively more academic scrutiny. The Tamil diaspora provides an example. A number of Sri Lankan and international migration scholars have studied different aspects of this diaspora. For example, Burgio (2016) analyzed the Sri Lankan Tamil diaspora as a model for transnational identity. Sankaran (2019) studied homehost identification in relation to the Tamil diaspora. Cheran (2003) studied the diasporic nature of the Sri Lankan Tamil migrant community and presented the concept of "diaspora circulation" as an effective tool for engaging diaspora in the development process in Sri Lanka. Wayland (2004) too studied the Sri Lankan Tamil community as a diaspora and a transnational entity. She specifically attempted to understand the formation of Tamil ethnic networks in receiving countries and the utilization of transnational opportunities to pursue political goals in Sri Lanka.

Exploring the Tamil diaspora's interest in engaging with home country (Sri Lankan) matters, Erdal (2006) declared that this diaspora population has a great contribution to make to the development of Sri Lanka. Meanwhile, while Orjuela (2008) looked at the Tamil diaspora's role in Sri Lanka's civil war, other scholars discussed the social aspects of Tamil immigrants' lives in host countries. For example, Beiser, Goodwill, Albanese and Mcshane (2015) studied the integration of Tamil migrants in Canada while Affleck, Thamotharampillai, Jeyakumar and Whitley (2018) explored the psycho-social experiences of Tamil refugees in Canada. A few scholars also specifically explored how Sri Lankan immigrants' religious practices at home are reproduced in host societies. Maunaguru (2015) studied how Hindu temples in host countries have become Tamil migrant hubs which collect money to transfer to Sri Lanka for a range of reasons, and how this situation has affected the host country. Jones (2016) investigated the Hindu religious practices of Sri Lankan Tamils in suburbs in the UK and how Tamils were affected by their migratory experiences and perceptions. David (2012) looked at the ways in which migratory experiences have affected the cultural performativity of Tamils and their ethnic identities.

\section{An Agenda for Future Research}

As described above, certain aspects of Sri Lankan migration have received adequate academic attention, but other aspects of the phenomenon need further investigation. For example, even now we lack academic explanations about the transnational political relationship of Sinhalese migrants with their home country. At the Presidential election of 2020, we saw the growing interest of Sri Lankan migrants in returning to vote at the polls, towards a responsibility to making their voice heard in Sri Lankan politics. This, I argue, is a new development in Sri Lankan migration, but due to the lack of information and knowledge on these migrants (predominantly Sinhalese Buddhists) and their political relationship with their home country, we are unable to assess the real impact people living outside the country can make in its internal matters. 
Other aspects that need further research include the return of Sri Lankan migrants (questions such as why do they come back?), Sri Lankan refugees' relations with Sri Lanka (what motivates them to continue their relations, or not, with Sri Lanka?), labour migrants' rights and conditions in the receiving countries, Sri Lankan pilgrim-tourists and emigration to Nigeria and Zambia. Parallel to global and national developments, the characteristics of contemporary Sri Lankan migration are changing very fast but we are unable to understand them due to a lack of comprehensive knowledge on migrations from Sri Lanka. Therefore, it is important to diversify the research on Sri Lankan migration to better understand it as a phenomenon.

\section{References}

Affleck, W., Thamotharampillai, U., Jeyakumar, J., \& Whitley, R. (2018). "If one does not fulfil his duties, he must not be a man": Masculinity, mental health and resilience amongst Sri Lankan Tamil refugee men in Canada. Culture, Medicine, and Psychiatry, 42(4), 840-861. https://doi. org/10.1007/s11013-018-9592-9

Arunatilake, N., Jayasuriya, S., \& Kelegama, S. (2001). The economic cost of the war in Sri Lanka. World Development, 29(9), 1483-1500. https://doi.org/10.1016/S0305-750X(01)00056-0

Athukorala, P., \& Jayasuriya, S. (2000). Trade policy reforms and industrial adjustment in Sri Lanka. The World Economy, 10(2), 387-404. https://doi.org/10.1111/1467-9701.00278

Australian Government. (2018). Fact sheet - Abolition of the "White Australia" policy. Retrieved June 27, 2018, from https://www.homeaffairs.gov.au/about/corporate/information/factsheets/08abolition

Bandarage, A. (2008). The separatist conflict in Sri Lanka: Terrorism, ethnicity, political economy. Routledge.

Beiser, M., Goodwill, A. M., Albanese, P., \& Mcshane, K. (2015). Predictors of the integration of Sri Lankan Tamil refugees in Canada: Pre-migration adversity, mental health, personal attributes and post-migration experience. International Journal of Migration, Health and Social Care, 11(1), 29-44. https://doi.org/10.1108/IJMHSC-02-2014-0008

Brown, B. (2018). Unlikely cosmopolitans: An ethnographic reflection on migration and belonging in Sri Lanka. Anthropological Quarterly, 91(1), 209-236. https://doi.org/10.1353/anq.2018.0006

Brown, B. E. (2014). From Guru Gama to Punchi Italia: Changing dreams of Sri Lankan transnational youth. Contemporary South Asia, 22(4), 335-349. https://doi.org/10.1080/09584935.2014.9635 14

Burgio, G. (2016). When interculturality faces a diaspora. The transnational Tamil identity. Encyclopaideia, 20(44), 106-128. https://doi.org/10.6092/issn.1825-8670/5992

Cassim, S. (2017). Oceans away: Sri Lankan migrants in New Zealand. The University of Waikato. Central Bank of Sri Lanka. (2019). Annual Report 2019. 
Cheran, R. (2003). Diaspora circulation and transnationalism as agents for change in the postconflict zones of Sri Lanka [Policy paper]. Berghof Foundation for Conflict Management.

Collyer, M., Wimalasena, P., Ansar, N., \& Ali Khan, M. (2009). Return migrants in Sri Lanka. Institute for Public Policy Research.

David, A. R. (2012). Embodied migration: Performance practices of diasporic Sri Lankan Tamil communities in London. Journal of Intercultural Studies, 33(4), 375-394. https://doi.org/10.108 0/07256868.2012.693815

Department of Census and Statistics. (2012). Population and Houses Census, Sri Lanka: 2012.

DeVotta, N. (2007). Sinhalese Buddhist nationalist ideology: Implications for politics and conflict resolution in Sri Lanka. Policy Studies, 40, 1-64.

De Silva, M. S. (1967). Effects of purism on the evolution of the written language: Case history of the situation in Sinhalese. Linguistics, 5(36), 5-17.

Dias, M., \& Jayasundere, R. (2002). Sri Lanka: Good practices to prevent women workers from going into exploitative forms of labour (GENPROM Working Paper No. 9). International Labour Office.

Dias, M., \& Jayasundere, R. (2004). Sri Lanka: The anxieties and opportunities of out-migration. In P.-S. Ahn (Ed.), Migrant workers and human rights: Out-migration from South Asia (pp. 153192). International Labour Organization.

Doherty, B. (2011, September 11). Lost in transportation: Tamil refugees in India and their dangerous gambles. Thuppahi's blog. Retrieved July 30, 2020, from https://thuppahi.wordpress. com/2011/09/10/lost-in-transportation-tamil-refugees-in-india-and-their-dangerous-gambles/

Eelens, F. (1995). Migration of Sri Lankan women to Western Asia. In International Migration Politics and the Status of Female Migrants (pp. 267-277). United Nations. https:// www.povertyportal.1k/resource-library/migration-of-sri-lankan-women-to-western-asiaE4K9D3zzwhXaR221iUEQMsy4uGreI3hG.html

Erdal, M. B. (2006). Contributing to development? Transnational activities among members of the Tamil diaspora in Norway. University of Oslo.

Farrag, M. (1997). Managing international migration in developing countries. International Migration, 35(3),315-336.

Galligan, B., \& Roberts, W. (2003). Australian multiculturalism: Its rise and demise. In Australasian Political Studies Association Conference. University of Tasmania.

Gamage, S. (1998). Curtains of culture, ethnicity and class: The changing composition of the Sri Lankan community in Australia. Journal of Intercultural Studies, 19(1), 37-56. https://doi.org/ https://doi.org/10.1080/07256868.1998.9963454

Gamage, S. (2002). Adaptation experiences of Sri Lankan immigrants and their children in Australia in the context of multiculturalism and Anglo-conformity. In A. Richardson, M. Wyness, \& E. 
A. Halvorsen (Eds.), Exploring cultural perspectives: Integration and globalization (pp. 3-29). International Cultural Research Network Press.

Government of Italy, Bossi-Fini law (2002), No. 189

Government of Italy, Dini Decree law (1995), No. 489

Henayaka-Lochbihler, R., \& Lambusta, M. (2004). The Sri Lankan diaspora in Italy: An explorative mapping. Bergof Research Centre for Conflict Management.

High Commission of India in Sri Lanka. (2020). India-Sri Lanka Bilateral Relations. Retrieved May 23, 2020, from https://hcicolombo.gov.in/pages?id=eyJpdiI6IkRGV0Nkb3VCRXNDc UVBM24yZ1V5TUE9PSIsInZhbHVIIjoiTDBBdm5VS0x6am9ZcDY3TEVTWURuQT09I iwibWFjIjoiYTA2MjZiNTY4ODQwZGMwZGU3NTI4MzM0ZjN1YmEyZjFjNDI0 YWM1MzEwOWU0ODBjODliYjBkZTcwYmE0NWZiNiJ9\&subid=eyJpdiI6IjNEQzlzc2o5 TDFMRE5zZmhSWmNIekE9PSIsInZhbHVIIjoiQ0xzRzBUVGIPQmpNTHp0aFd1OFBkdz09 IiwibWFjIjoiNDlkNzdhNDcxZWQ5 MGMyNzFkOT11YzUxMTc0NDAw MmQ2 NTMwYmZmMDgzZDMwNWJmM2VhN2I4OGFmNzZkNDQ4YyJ9

Hodge, A. (2012, September 25). 18 Lankan asylum seekers choose return to Sri Lanka rather than going to Nauru. Thuppahi's Blog. Retrieved from https://thuppahi.wordpress.com/2012/09/25/18lankan-asylum-seekers-choose-return-to-sri-lanka-rather-than-go-to-nauru/

Horowitz, D. L. (1980). Coup theoried and officers' motives: Sri Lanka in comparative perspective. Princeton University Press.

Howie, E. (2013). Sri Lankan boat migration to Australia: motivations and dilemmas. Economic and Political Weekly, 48(35), 97-104.

Hugo, G., \& Dissanayake, L. (2017). The process of Sri Lankan migration to Australia focusing on irregular migrants seeking asylum. In M. McAuliffe \& K. Koser (Eds.), A long way to go: Irregular migration patterns, processes, drivers and decision-making (pp. 197-226). ANU Press. https://doi.org/dx.doi.org/10.22459/LWG.12.2017.08

Hugo, G., \& Ukwatta, S. (2010). Sri Lankan female domestic workers overseas - the impact on their children. Asian and Pacific Migration Journal, 19(2), 237-263.

International Crisis Group. (2010). The Sri Lankan Tamil diaspora after the LTTE. Retrieved May 16, 2018, from https://d2071 andvip0wj.cloudfront.net/186-the-sri-lankan-tamil-diaspora-afterthe-ltte.pdf

Jayasuriya, D., \& McAuliffe, M. (2017). Placing Sri Lankan maritime arrivals in a broader migration context. In M. Mcauliffe \& K. Koser (Eds.), A long way to go: Irregular migration patterns, processes, drivers and decision-making (pp. 49-76). Australian National University Press.

Jones, D. (2016). Being Tamil, being Hindu: Tamil migrants' negotiations of the absence of Tamil Hindu spaces in the West Midlands and South West of England. Religion, 46(1), 53-74. https:// doi.org/10.1080/0048721X.2015.1027968 
Kivisto, P., \& Faist, T. (2010). Beyond a border: The causes and consequences of contemporary immigration. Sage.

Koleth, E. (2010). Multiculturalism: A review of Australian policy statements and recent debates in Australia and overseas. Department of Parliamentary Services.

Kymlicka, W. (2003). Immigration, citizenship, multiculturalism: Exploring the links. The Political Quarterly, 74, 195-208. https://doi.org/10.1111/j.1467-923X.2003.00590.x

Maunaguru, S. (2015). Amman as social auditor: Financial misconduct versus charitable giving by Tamil Sri Lankans in the UK. Contributions to Indian Sociology, 49(3), 369-388.

Näre, L. (2010). Sri Lankan men working as cleaners and carers: Negotiating masculinity in Naples. Men and Masculinities, 13(1), 65-86.

Office of Multicultural Affairs. (1989). National agenda for a multicultural Australia. Australian Government Publishing Service.

Orjuela, C. (2008). Distant warriors, distant peace workers?: Multiple diaspora roles in Sri Lanka's violent conflict. Global Networks, 8(4), 436-452. https://doi.org/10.1111/j.14710374.2008.00233.x

Pagonis, J. (2010). Coming home: Sri Lankan refugee return. The United Nations High Commission for Refugees. Retrieved May 23, 2020, from http://www.unhcr.org/4c657ec69.html

Pathirage, J., \& Collyer, M. (2011). Capitalizing social networks: Sri Lankan migration to Italy. Ethnography, 12(3), 315-333.

Perera, N. (2020). Tamil weekends: Intergenerational perspectives on belonging. In A sense of viidu: The (re)creation of home by the Sri Lankan Tamil diaspora in Australia (pp. 137-154). Palgrave Pivot.

Pingama, A. (2016). Reasons for youth migration in Sri Lanka with emphasis on regular and irregular youth migrants. In 2nd International Conference on the Humanities. University of Kelaniya, Sri Lanka.

Pinnawala, S. K. (1984). Sri Lankans in Melbourne: Factors influencing patterns of ethnicity. Australian National University.

Ratnapalan, L. M. (2014). Before and after 1983: The impact of theorising Sri Lankan Tamil migration history around the 1983 Colombo riots. South Asia: Journal of South Asian Studies, 37(2), 281-291. https://doi.org/10.1080/00856401.2014.882874

Ratnayake, K. (1999). Female migration from Sri Lanka to the Middle East: Is remedy worse than the disease? Sri Lanka Journal of Population Studies, 2, 43-56.

Reeves, P. (2013). The encyclopedia of the Sri Lankan diaspora. (P. Reeves, Ed.). Editions Didier Millet.

Roberts, M. (1983). "Our duty to act": Brown sahibs in universal suits. A review article on the abortive 1962 coup in Sri Lanka. South Asia: Journal of South Asian Studies, 6(2), 62-77. 
Roberts, M. (2005). Sri Lanka: The power of cricket and the power in cricket. In S. Wagg (Ed.), Cricket and national identity in the postcolonial age: Following on. Routledge.

Samaranayake, G. (1990). Political violence in the third world: A case study of Sri lanka, 1971-1987. University of St. Andrews, Scotland.

Sankaran, L. (2019). "Homeland" \& "hostland" identifications in the Sri Lankan Tamil diaspora (Working Papers in Urban Language and Literacies). King's College London.

Singham, M. (2006). Multiculturalism in New Zealand - the need for a new paradigm. Aotearoa Ethnic Network Journal, 1(1), 33-37. http://www.aen.org.nz/journal/

Siriwardhana, C., \& Wickramage, K. (2014). Conflict, forced displacement and health in Sri Lanka: A review of the research landscape. Conflict and Health, 8(22), 1-9. https://doi.org/10.1186/1752$1505-8-22$

Sriskandarajah, D. (2002). The migration-development nexus: Sri Lanka case study. International Migration, 40(5), 283-307. https://doi.org/10.1111/1468-2435.00220

Sri Lanka Bureau of Foreign Employment Act, No. 20 (1985)

Sri Lanka Tourism Development Authority. (2018). Annual statistical report 2018.

Ukwatta, S. (2013). Sri Lanka, migration 1960s to present. The Encyclopedia of Global Human Migration.

United Nations High Commission for Refugees (2006). UNHCR position on the international protection needs of asylum-seekers from Sri Lanka.

Wanasinghe-Pasqual, M., \& Jayawardena, P. (2017). Sri Lanka's illegal migration: Detriment to development. In International Research Conference, Faculty of Arts. The University of Colombo.

Wayland, S. (2004). Ethnonationalist networks and transnational opportunities: The Sri Lankan Tamil diaspora. Review of International Studies, 30(3), 405-426. https://doi.org/10.1017/ S0260210504006138

Weerasooria, W. S. (1988). Links between Sri Lanka and Australia: A book about Sri Lankans (Ceylonese) in Australia. Government Printer.

Wijayasiri, J. (2019, November 26). Helping Sri Lankan workers in South Korea to save better. Daily Mirror. http://www.dailymirror.lk/features/Helping-Sri-Lankan-workers-in-South-Koreato-save-better/185-178488

Yang, P. Q. (1994). Explaining immigrant naturalization. International Migration Review, 28(3), 449-477. https://doi.org/10.2307/2546816

Zubrzycki, J. (1995). The evolution of the policy of multiculturalism in Australia 1968-1995. In Global Cultural Diversity Conference Proceedings. Sydney, NSW: Department of Immigration and Multicultural and Indigenous Affairs. 